\title{
The Goethe Institute and Soft Power
}

\section{T. Lanshina}

Tatiana Lanshina - Junior Researcher at the International Organisations Research Institute, National Research University Higher School of Economics; Researcher at the Laboratory for Corporate Strategy and Firm-Level Behavior Research; Researcher at the Industrial Research Centre; 20 Myasnitskaya, 101000 Moscow, Russian Federation; E-mail: lanshina.ta@gmail.com

This article deals with the history, evolution and working methods of Goethe - Institute, a key German soft power actor. It examines the institute's activities in fulfilling the main functions assigned to it by the German Ministry for Foreign Affairs (promoting the German language and supporting cultural events) and provides a thorough study of Goethe Institute's projects in 15 European, Asian, African, North and South American countries, namely in Argentina, Brazil, China, France, Germany itself, Italy, India, Japan, Kazakhstan, Mexico, South Africa, the United Kingdom, the United States, Uzbekistan and Ukraine. It finds that while in general the forms and methods used in all these regions are generally similar, specific features are characteristic of United Kingdom, the United States, Japan, India and South Africa.

This analysis offers valuable recommendations for Russian cultural centres. The author argues that placing centres for learning Russian as a foreign language in towns with vast historical and cultural heritage as well as with developed infrastructure and good transport in Russia, using non-conventional and innovative language and cultural interaction methods, and partnering with other educational, scientific and cultural institutes such as libraries, universities and foreign cultural centres, is crucial for Russian cultural centres as subjects of Russian soft power.

Key words: soft power, German language, international cultural exchange, Goethe Institute

Founded in 1951 as successor to the established in 1925 German Academy, the Goethe Institute started with training foreign German teachers in Germany. Since that time, tasks of the Goethe Institute have been deepening, growing in complexity, and covering more and more regions of the world.

The tasks of the German Academy were similar to the modern tasks of the Goethe Institute: research and diffusion of the German culture as well as the promotion of the German language. However, in the Third Reich the Academy destroyed its reputation by accepting the Nazi ideology and breaking off its former cultural relationships. Therefore, in post-war Germany it was impossible to keep its original form and original name. Nonetheless, in the 1950s, the Goethe Institute was not created from scratch.

The fact that the new institute was named after the German poet and statesman Johann Wolfgang von Goethe, who considered himself a citizen of the world and adhered to the values and ideas of humanism, had a considerable impact on the image of the institute.

In 1953, the Goethe Institute started its first German-language courses in Bad Reichenhall, a small town in Germany. High demand for these courses encouraged the creation of educational centres in Murnau and Kochel. In those years soon after the war, the new institute preferred towns, which could present Germany in the best possible way.

In early 1960s, Dieter Sattler, the head of the arts section of the German Federal Foreign Office, gradually began consolidating the German cultural centres abroad under the auspices 
of the Goethe Institute. This marked the beginning of the institute's active network-building process and of Germany's strong cultural policy. Societal and political issues and avant-garde art became part of the Goethe' Institute's cultural events program.

In 1976, Germany's Foreign Office and the Goethe Institute signed a framework agreement making it an independent cultural organization. In 1980s, Goethe Institute's educational centres in small German towns were replaced by institutes in cities and university towns. After the fall of communism in Eastern Europe, the Goethe Institute focused its activities on this region.

Today the Goethe Institute is a German cultural institute with a global network of 159 institutes in 94 countries; 13 including the headquarters are located in Germany. In 2012-13 the organization employed approximately 3,000 people, with 2,300 of them working abroad [Goethe Institute, 2013].

The Goethe Institute sets standards for teaching and learning German as a foreign language, which are recognized at the international level. More than 500,000 people attend these courses or take examinations in German (about $50 \%$ take courses and $50 \%$ take exams). The Goethe Institute provides advisory services and works to improve professional competence of German-language teachers in more than 100,000 schools worldwide, creating innovative educational materials for teachers and students. It also supports research activities and regularly initiates new projects in language policy to promote German language [Goethe Institute, 2014].

The Goethe Institute maintains international cultural cooperation through cultural events, cultural exchange and the dissemination of information on German cultural, social and political life. Such projects also support intercultural dialogue, strengthen civil society and develop mobility.

The main aims of the Goethe Institute, including setting standards for teaching German and engaging in international cultural cooperation, are set out by the Foreign Office in line with the framework agreement between the Federal Republic of Germany and the Goethe Institute [Goethe Institute, 2004] The organization can take on other tasks, as indicated in the agreement.

According to the Goethe Institute agreement, this institution is a registered non-profit association (eingetragener Verein, e.V.), like most other soft power organizations in Germany. Institute members receive no payment for their membership from the organization's funds [Goethe Institute, 2009].

The German Foreign Office and the Goethe Institute cooperate closely. The Foreign Office invites the Goethe Institute to its meetings and consultations relating to the institute's activities and keeps it informed about new orders and reports of foreign delegations. The Goethe Institute reports on its achievements to the German Foreign Office and regularly holds meetings with officials from the Foreign Office.

To perform its functions, the Goethe Institute has established a broad worldwide network of cultural institutes and representative offices and launched partner relations with foreign organizations. These relations usually take the forms of cultural societies or Goethe Centres, libraries or information and learning centres, German-language learning centres and examination centres. These are described in more detail below.

- Cultural societies and Goethe Centres. Cultural societies are foreign societies supported by their national cultural institutions, and engage in cultural exchanges with Germany. The Goethe Institute provides these societies with annual funding for projects and allows them to offer German-language courses and various cultural programs. There are 30 cultural societies with cooperation treaties with the Goethe Institute to become Goethe Centres. According to these treaties, Goethe Centres are obliged to operate under the 
standards of the Goethe Institute. Cultural societies and Goethe Centres in selected countries are described later in this article.

- Libraries and information and learning centres. The Goethe Institute supports 77 libraries and information and learning centres worldwide, providing information and media on German language and culture. Libraries in turn disseminate these materials among all interested people.

- German-language learning centres. These centres are usually at foreign universities and offer courses following the model and supervision of the Goethe Institute's professional standards, acting as partners of the Goethe Institute. The Goethe Institute provides supports through training employees, providing learning materials and equipment, and consulting with staff on teaching methods and management. German-language learning centres in selected countries are described later in this article.

- Examination centres. There are 307 licensed partner examination centres operating under the supervision of the Goethe Institute These centres also usually offer preparatory courses. Examination centres in selected countries are described later in this article.

Partnering with other organizations, such as universities, embassies, trade missions and companies, plays a very important role in the work of Goethe Centres. It allows them to increase the level of activity without opening new institutes and without increasing the number of employees. It also allows them to use buildings and equipment of the partners and to attract sponsors and audiences.

\section{Promoting the German Language}

The main instrument used by the Goethe Institute is language courses for students with different levels of knowledge of German, including courses customized for individuals or smaller groups and special interest courses for those who want to discuss specific topics such as literature, history, medicine and business. The institute also offers interactive learning games and forums, where students can practise German free of charge.

There are fee-paying online language courses as well, where students can choose between several specialist areas. Every online student has a personal tutor. At the end of the course the student receives a certificate.

Over the last decade, the number of students learning German at Goethe Institutes has significantly increased, both in Germany and abroad (see Figure 1). The number of people taking examinations has shot up dramatically: from fewer than 80,000 in 2003 to more than 240,000 in 2013 [Goethe Institute, 2014].

The Goethe Institute certificate confirms the language competence of the student and is internationally recognized by universities and other educational institutions, as well as by employers. A1 and A2 certificates indicate elementary skills (A2 is for those who have deeper knowledge). B1 and B2 certificates confirm that the student has independent language skills (B2 is for more advanced students who can understand complex texts and communicate spontaneously). A $\mathrm{C} 1$ certificate requires autonomous language ability, which means the ability to understand long texts and television programs, reports, and so on, as well as the ability to write and speak about complex topics. The highest level is $\mathrm{C} 2$, which indicates a fluent grasp of German.

The Goethe Institute is the leading organization offering courses for non-native German-language teachers both in their own countries and in Germany. Distance learning is also possible. The institute grants scholarships to highly motivated teachers from other countries: the winners attend language courses in Germany. Sometimes the institute organizes summer schools for German-language teachers. 


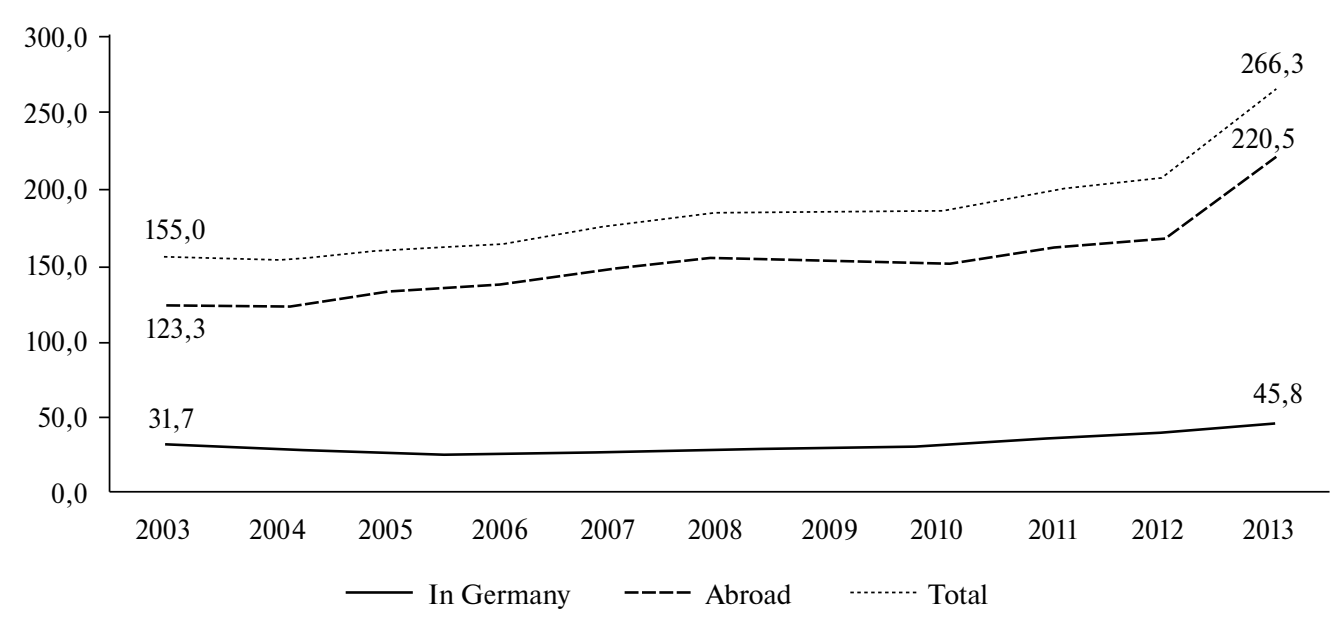

Fig. 1. Number of Goethe-Instituts' German language students, 2003-2013, thousands

Source: Goethe Institute [2014].

The Goethe Institute is also very engaged in developing the German language. It promotes six programs and incentives, which are described below.

- Debating Language and Its Future (Deutsch 3.0). According to a survey, 78.4\% of German citizens believe that more needs to be done for the German language, which changes considerably as a result of social and political developments. The Goethe Institute, Duden, the Institute for the German Language, and the Association for the Promotion of Science and Humanities initiated Deutsch 3.0, a discussion on the German language and its future. Deutsch 3.0 explores societal and political issues, such as how many languages does the world need, how is the German language changing and how many languages will survive in the future. The project promotes an open discussion on the future of German. ${ }^{1}$

- Schools: Partners of the Future (PASCH). This initiative (Partnerschulinitiative PASCH) plays an important role in promoting German. PASCH was proposed by German foreign minister Frank-Walter Steinmeier in 2008 to increase interest in Germany and the German language among foreign youth, especially in Asia, the Middle East, and Central and Eastern Europe. The Foreign Office produces this program in cooperation with the Central Agency for Schools Abroad (ZfA), the Goethe Institute, the German Academic Exchange Service (DAAD) and the Pedagogical Exchange Service (PAD). Partner schools enjoy assistance and consultations with German teachers and experts and receive teaching materials and equipment. Their students can participate in various projects and competitions and take German courses in Germany. There are four types of PASCH schools:

- German schools abroad (Deutsche Auslandsschulen, DAS), assisted by the Central Agency for Schools Abroad;

- schools in the national education system, assisted by the Central Agency for Schools Abroad, which offer German-language diplomas issued by the Education Ministers Conference (DSD-Schulen);

- schools in the national education system with extended German classes (FIT-Schulen), assisted by the Goethe Institute; and

${ }^{1}$ See Goethe Institute, "Deutsch 3.0: Debatten über Sprache und Ihre Zukunft” at https://www.goethe. de/de/spr/eng/d30.html. 
- schools in Germany that cooperate with foreign PASCH schools through the Pedagogical Exchange Service.

PASCH covers 1,700,000 schools worldwide. One third of these schools are assisted by the Goethe Institute The largest numbers of partner schools are in China (67), India (42), Indonesia (28), Brazil (22), Turkey (19), Egypt (18) and Ukraine (15) [Goethe Institute, 2014]. All PASCH schools have especially close ties with Germany and ties with other programs in the sphere of culture and education, for instance, with the "German - Language of Ideas", initiative. $^{2}$

- Language and Mobility. Language and mobility are central to the Goethe' Institute's activities, since language is the key toward integration of those who encounter a new culture or try to understand it. This project creates an informational link between Goethe Institutes in different countries to address language and intercultural qualifications for immigrants as well as information and advice on living and working in Germany. ${ }^{3}$

- European Network for the German Language (formerly the DeutschLand initiative). Through this program the Goethe Institute offers exclusive German-language courses in Germany to a select group of people. The target audience consists of high-ranking staff of European Union institutions and senior ministry officials from EU member states and other countries who want to improve their German skills for use in their work. ${ }^{4}$

- German Minorities in Central and Eastern Europe and Central Asia. A large number of people with a German background still live in Central and Eastern Europe and in Central Asia. The Goethe Institute supports these groups through cultural and educational programs, with the goal of communicating a comprehensive image of Germany, promoting extracurricular study of German and offering German courses for adults. Goethe Institutes support national minorities in Russia, Poland, Ukraine, Slovakia, Czech Republic, Hungary, Rumania, Moldova, Georgia, Kazakhstan, Kyrgyz Republic, Latvia, Lithuania and Estonia. ${ }^{5}$

- Alumni Portal. This project promotes networking among foreign alumni of German universities (and language courses) and their former German course mates. The portal was launched in September 2008. It also offers news, articles, advice and job opportunities, similar to other alumni portals. ${ }^{6}$

\section{Supporting Cultural Events}

The Goethe Institute supports cultural events in architecture, education, fashion, design, literature, media, music and theatre. In 2012, the organization held 5,800,000 cultural events worldwide. About 25 million people were involved in these events, including 269 researchers, artists and journalists, who experienced new cultural environments and made contacts with their colleagues from other countries. Figure 2 shows the distribution of Goethe Institute's events.

The Goethe Institute's cultural activities include the following:

- Visual Arts. Together with local partners, the Goethe Institute initiates and promotes group and individual exhibitions in all areas of the visual arts: sculpture, painting, graphic arts, photography, architecture, media art, design and fashion. It organizes touring exhi-

\footnotetext{
${ }^{2}$ See Schulen: Partner der Zukunft, "Angebot" at http://www.pasch-net.de/udi/ang/deindex.htm.

${ }^{3}$ See Goethe Institute, "Sprache und Mobilitaet" at https://www.goethe.de/de/spr/eng/mob.html.

${ }^{4}$ See Goethe Institute, "Europanetzwerk Deutsch" at https://www.goethe.de/en/spr/eng/eur.html.

${ }^{5}$ See Goethe Institute, "Deutsche Minderheiten” at https://www.goethe.de/de/spr/eng/min.html.

${ }^{6}$ See Goethe Institute, "Alumniportal Deutschland” at https://www.goethe.de/de/spr/eng/alu.html.
} 


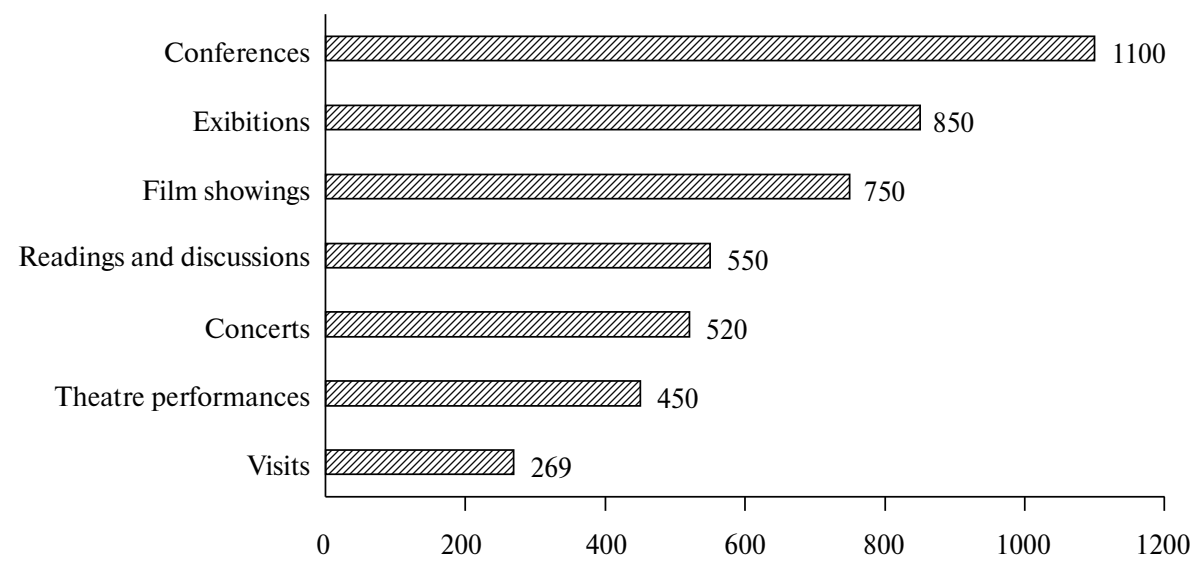

Fig. 2. Goethe Institute Cultural Events in 2012

Source: Goethe Institute [2013]

bitions that document historical events or historical themes, conferences, seminars and visits, - totalling about 1,000 events every year. These activities inform the local society about important trends in modern German art.

- Films, Television and Radio. Each year, 136 Goethe Institutes organize about 2,500,000 film screenings, showing not only modern German films but also silent classics. The institute holds seminars with German and foreign representatives of the film industry. Film screenings may take place at universities and, in some countries, in special buses or trains (e.g., in Morocco and Indonesia).

The Goethe Institute pays much attention to cooperation with regard to quality television in transition countries. Together with Deutsche Welle and other broadcasters, it organizes seminars for journalists, especially in developing and transition countries. ${ }^{7}$

- Music. The Goethe Institute communicates a comprehensive image of musical life in Germany and initiates cultural exchange between musicians in Germany and other countries. Every year it holds approximately 1,000 musical events such as concerts, tours, seminars and workshops. These activities involve all musical genres: early and classical music, rock, pop, jazz and more. Professional musicians who live and work in Germany can receive financial support from the Goethe Institute for tours, promotion of extended stays abroad and information dissemination. Musicians from developing and transition countries can receive financial support to organize concerts in Germany. ${ }^{8}$

- Theatre and Dance. The Goethe Institute introduces German theatre and dance to the foreign public, especially drama, performance, modern dance, puppet and marionette theatre. The institute promotes performances of German groups abroad, as well as their visits to other countries, and gives residencies to foreign artists for stays in Germany. It also funds performances of groups from developing and transition countries in Germany and cooperates with German festivals and organizing committees. ${ }^{9}$

- Literature. The Goethe Institute strengthens international cooperation in literature and promotes German literature in other countries. It works to expand contacts and to co-

\footnotetext{
${ }^{7}$ See Goethe Institute, "Film, Fernsehen, Hörfunk" at https://www.goethe.de/de/uun/auf/ffh.html.

${ }^{8}$ See Goethe Institute, "Musik" at https://www.goethe.de/de/uun/auf/mus.html.

${ }^{9}$ See Goethe Institute, "Tanz und Theater" at https://www.goethe.de/de/uun/auf/tut.html.
} 
ordinate large international events, such as book exhibitions. The Goethe Institute also cooperates with the book trade industry and various literary institutions, including Literaturhäuser ("literature houses"), the Literaturwerkstatt Berlin, the Literarisches Colloquium Berlin, literature archives, museums and foundations (e.g., Alfred Töpfer Stiftung, Robert Bosch Stiftung and other).

Since 2008, the institute offers four residencies for foreign literature translators. These grants allow inviting qualified translators to translate German fiction during their four to six weeks visits to Germany. ${ }^{10}$

- Science and Current Affairs. The Goethe Institute participates in discussions on topical issues in the humanities, social and cultural sciences, which are much debated in media. It raises questions, answers to which are actively sought by German and European researchers. Such questions explore the relationship between culture and climate change, culture and economy, and culture and conflicts. The Goethe Institute offers programs for specific subject-related visits of foreign experts to Germany and provides opportunities for advanced training for its staff. It cooperates with universities, foundations, media and independent cultural organizations in Germany and worldwide. "Germany Thinks" ("Deutschland Denkt") is a network of German research institutions that cooperate with the Goethe Institute. ${ }^{11}$

\section{The Funding of the Goethe Institute}

About $60 \%$ of the Goethe Institute's funding comes from the German Foreign Office. The institute also charges fees for courses and examinations, usually adjusted to market prices and to cover costs, since it is a non-profit organization [Goethe Institute, 2014]. Individual projects are often financed by sponsors, including large German or international corporations such as Airbus Group, Audi, BMW Group, Commerzbank, Siemens and Volkswagen. Projects are also financed by individuals.

Figures 3 and 4 illustrate the Goethe Institute's income and cost structure for 2013. Its total income for that year was $€ 350.9$ million.

$208.1 ; 59,3 \%$

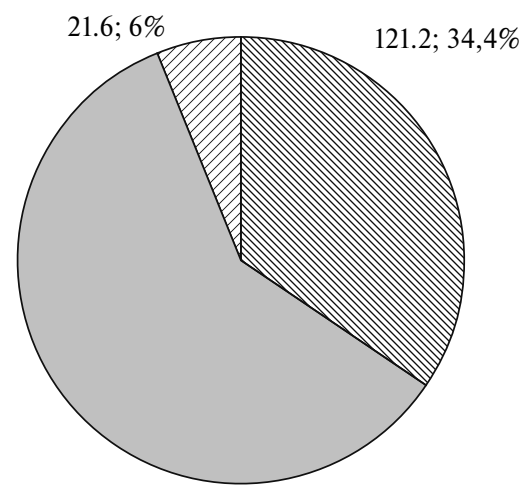

German-language course tuition and examination fees

Grants from the German Foreighn Office

Other Income

Fig. 3. Income Structure of the Goethe Institute in 2013, € million and \%

Source: Goethe Institute [2014].

${ }^{10}$ See Goethe Institute, "Literatur" at https://www.goethe.de/de/uun/auf/lit.html.

${ }^{11}$ See Goethe Institute, "Wissenschaft und Zeitgeschehen" at https://www.goethe.de/de/uun/auf/wuz. html. 


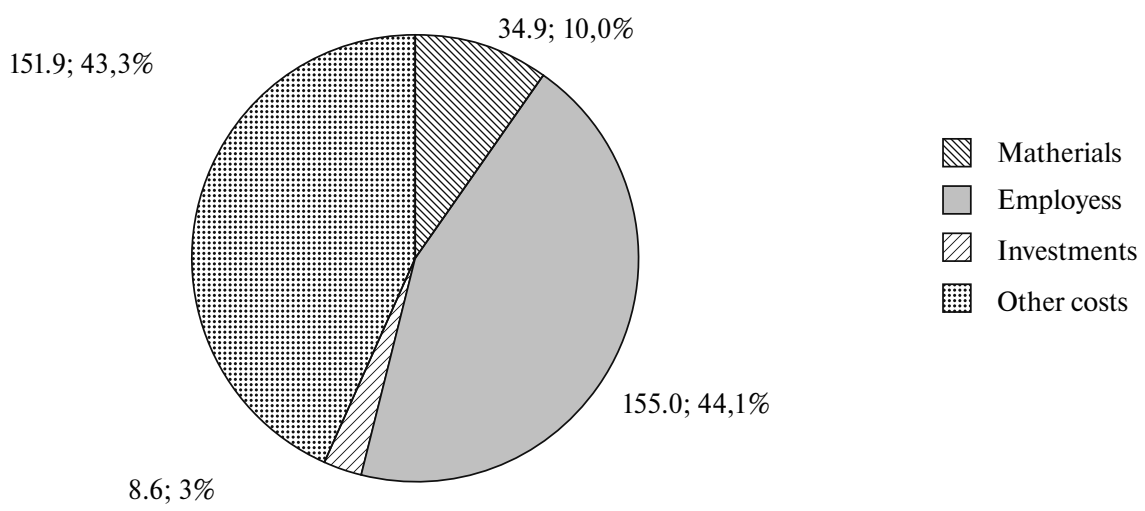

Fig. 4. Cost Structure for the Goethe Institute in 2013, € million and \%

Source: Goethe Institute [2014].

\section{Country Case Studies}

This section analyzes the activities of the Goethe Institute in 15 countries where the institute has a representative or a branch office (all are non-profit organizations). Partnerships with local universities, cultural centres and libraries result in Goethe Centres, German-language learning centres, examination centres and libraries. These are also non-profit activities. Table 1 summarizes on activities in the countries discussed below.

\section{Argentina}

The Goethe Institute started working in Argentina in 1967, in Buenos Aires. Its activities are sponsored by the German insurance company Allianz and by the Argentinian small business Maria Elena S.A. ${ }^{2}$ The Goethe Institute now has two offices in Argentina with 32 employees in Buenos Aires and Cordoba, two Goethe Centres, nine cultural societies and 10 partner examination centres. It assists 11 PASCH schools in five cities. The budget in Argentina is estimated at $€ 3.7$ million.

As in other countries, the Goethe Institute in Argentina promotes a number of cultural initiatives, both national and international. For instance, Argentina is covered by the international PASCH Initiative. In April and May 2014, the Goethe Institute Buenos Aires held events for writers and translators during the 40th international book exhibition in Buenos Aires. German author Nina Jäckle visited Buenos Aires for the first time. ${ }^{13}$

\section{Brazil}

The first Goethe Institute in Brazil was established in 1963 in São Paolo. ${ }^{14}$ Nowadays Brazil has five Goethe Institute offices with 85 employees in São Paulo, Rio de Janeiro, Curitiba, Porto Alegre and Salvador. It also has one Goethe Centre, six cultural societies and 18 partner

\footnotetext{
dex.htm.

${ }^{12}$ See Goethe Institute Buenos Aires, "Förderer" at http://www.goethe.de/ins/ar/bue/uun/spo/dein-

${ }^{13}$ See Goethe Institute Buenos Aires, "Deutschland auf der 40. Internationalen Buchmesse Buenos Aires" at http://www.goethe.de/ins/ar/bue/ver/acv/lit/2014/de12642857v.htm.

${ }^{14}$ See Goethe Institute São Paolo, "50 Jahre Goethe-Institut São Paulo” at http://www.goethe.de/ins/ br/sap/uun/jub/deindex.htm.
} 
examination centres. The Goethe Institute assists 22 PASCH schools in 18 cities. The budget in Brazil is estimated at $€ 9.9$ million.

In addition to teaching German and organizing examinations, Goethe Institutes promote international cultural exchanges through a wide number of cultural and academic events held jointly with their Brazil partners. The Goethe Institute's library in Rio de Janeiro and other information centres provide comprehensive information on cultural, political and societal life in Germany. ${ }^{15}$

Examples of local projects include:

- Football and culture. Football is a national entertainment in Brazil so it is a relevant topic for discussions such as football in literature and film, football and music, and football and children. ${ }^{16}$

- German literature in Brazil. The Goethe Institute holds German-Brazil seminars for translators, and international translators have opportunities to win residencies to work in Germany to translate a German book. ${ }^{17}$ The Goethe Institute has similar projects in other countries.

- The Goethe Institute São Paulo, like many other offices of the organization, has a film library of 250 German documentaries and features. It provides these films free of charge for events in Brazil and for educational purposes. ${ }^{18}$

\section{China}

China has three Goethe Institute offices with 83 employees in Peking, Shanghai and Hong Kong, seven German-language learning centres, two libraries and six partner examination centres. There are no Goethe Centres in China, but 65 schools are assisted in 23 Chinese cities. Among the sponsors of the Goethe Institute in China is the Chinese Association for Relief and Ensuring Services. The budget in China is estimated at €9.7 milion.

Recent projects in China include:

- Museum employees' exchange program. This project was produced in 2010-12 to facilitate the cultural exchange between state museums of Berlin (Staatlichen Museen zu Berlin), Dresden State Art Collections (Staatlichen Kunstsammlungen Dresden), Bavarian State Painting Collections (Bayerischen Staatsgemäldesammlungen München) and the National Museum of China. It was renewed in in 2014. ${ }^{19}$

- The year 2013-14 was celebrated as "German-Chinese Year," with events designed to intensify the cultural exchange between Germany and China, including silent film screenings, theatre performances and concerts. ${ }^{20}$

- The promotion of German literature. Chinese Goethe Institutes provide financial support for translating selected books on social and human sciences drawn from a short list of books (approximately eight books) recommended for translation twice a year. The Goethe

\footnotetext{
${ }^{15}$ See Goethe Institute Rio de Janeiro, "Über uns” at http://www.goethe.de/ins/br/rio/uun/deindex. htm.

${ }^{16}$ See Goethe Institute São Paolo, "Fussball und Kultur” at http://www.goethe.de/ins/br/sap/prj/fus/ deindex.htm

${ }^{17}$ See Goethe Institute Brazil, "Deutsche Literatur in Brasilien” at http://www.goethe.de/ins/br/lp/prj/ dgb/deindex.htm.

${ }^{18}$ See Goethe Institute Brazil, "Filmarchiv Sao Paolo, Brasilien” at http://www.goethe.de/ins/br/lp/ $\mathrm{kul} / \mathrm{ser} / \mathrm{flm} / \mathrm{deindex} . \mathrm{htm}$.

${ }^{19}$ See Goethe Institute Peking, "Museum Experts Exchange Program (MEEP)," at http://www.goethe. de/ins/cn/de/pek/ver.cfm?fuseaction=events.detail\&event_id=12794070.

${ }^{20}$ See Goethe Institute China, "Deutsch-Chinesisches Sprachenjahr 2013/2014, China,” at http://www. goethe.de/ins/cn/lp/dll/dcs/deindex.htm.
} 
Institute may also support books from the long list, which usually includes approximately 15 books. ${ }^{21}$

\section{France}

The first Goethe Institute in France was established in 1962 in Paris. ${ }^{22}$ France now has seven Goethe Institute offices with 168 employees in Paris, Strasbourg, Toulouse, Lyon, Nancy, Bordeaux and Lille. It also has 11 cultural societies and 24 partner examination centres, but no Goethe Centres. It assists eight schools in eight cities. Among its partners in France are Mercedes-Benz, Vorwerk, International Art Centre in Paris (Cité Internationale des Arts Paris), Bionade, EnBW, Alternative Food\&Beverage, Lufthansa and Société Générale. ${ }^{23}$ The budget for France is estimated at $€ 19.6$ million.

Recent Goethe Institute projects in France include:

- “Common Gardens.” In 2014, school children in France's Lille and Germany's Witten planted gardens to commemorate the longstanding friendship between France and Germany. ${ }^{24}$

- "Somewhere." In May 2014, the Goethe Institute in Nancy held an exhibition of the German photographer Mona Breede during the 18th Biennale Internationale de l'Image de Nancy. ${ }^{25}$

- “Über 1914|18." Among the projects to commemorate centenary since the beginning of World War I in 1914, the Goethe Institute in Lille held a poetry slam in 2014, where French school students read poems dating from the war. ${ }^{26}$

\section{Germany}

In Germany there are 13 Goethe Institutes in Berlin, Hamburg, Frankfurt-on-Main, Dresden, Bremen, Gottingen, Weimar, Dusseldorf, Bonn, Mannheim/Heidelberg, Schwaebisch-Hall and Freiburg, with the headquarters in Munich. There are 321 schools that cooperate with schools abroad to teach German. The budget of the Goethe Institutes in Germany is estimated at $€ 81.8$ million.million

The Goethe Institutes in German cities offer their students not just German courses and examinations but also cultural programs that provide insights into modern Germany. Students usually can choose between excursions, exhibitions, museums, concerts, theatre performances and film screenings. ${ }^{27}$

Recent activities include:

- Summer scholarships for the best students from Frankfurt twin cities: In July 2014, the Goethe Institute Frankfurt and the Polytechnic Society of Frankfurt produced this pro-

\footnotetext{
${ }^{21}$ See Goethe Institute China, "Übersetzungsförderung," at http://www.goethe.de/ins/cn/lp/kul/ser/ uef/deindex.htm.

${ }^{22}$ See Goethe Institute Paris, "Zeitreise," at http://www.goethe.de/ins/fr/par/uun/j50/zei/deindex. htm.

${ }^{23}$ See Goethe Institute Paris, "50 Jahre Goethe-Institut Paris," at http://www.goethe.de/ins/fr/par/ uun/j50/deindex.htm.

${ }^{24}$ See Goethe Institute, "Gemeinsame Gärten,” at http://blog.goethe.de/garten.

${ }^{25}$ See Goethe Institute Nancy, “18. Biennale Internationale de l'Image de Nancy,” at http://www.goethe. de/ins/fr/nan/ver/acv/bku/2014/de12429267v.htm.

${ }^{26}$ See Goethe Institute, "Kriegslyrik und Slam Poetry: ein Workshop für Schüler,” at http://www.goethe. de/ges/prj/nzv/prj/de13163086.htm.

${ }^{27}$ See Goethe Institute Germany, "Kultur- und Freizeitprogramm,” at http://www.goethe.de/ins/de/ ler/kul/deindex.htm.
} 
gram for the seventh time. Students from Birmingham, Lyon, Yokohama and other twin cities of Frankfurt received scholarships to study in Frankfurt. ${ }^{28}$

- "Make It in Germany." This is an initiative of the Ministry for Economic Affairs and Energy, the Ministry of Labour and Social Affairs and the Agency for Employment in collaboration with several organizations including the Goethe Institute. It informs international qualified professionals about career opportunities in Germany and moving to Germany. The project's website also provides German employers with information on international professionals. ${ }^{29}$

- "Tandem" program for students of German to find native speakers with whom they can practise German. This program does not substitute for German-language courses, but helps people improve their speaking skills. ${ }^{30}$

\section{India}

The first Goethe Institute in India was established in 1957 in Calcutta. ${ }^{31}$ Today India has six Goethe Institute offices with 227 employees in New Delhi, Bangalore, Mumbai, Chennai, Pune and Calcutta, and seven Goethe Centres. It assists 44 schools in 15 cities. Because there are no partner examination centres, examinations can be taken only at Goethe Institutes and Goethe Centres. The budget for India is estimated at $€ 26.5$ million.

As in other countries, Goethe Institutes in India offer German courses, popularize German language and culture, and convey a comprehensive image of life in Germany. The cultural program in Pune focuses on films, since Pune is the home of the Film and Television Institute of India and the National Film Archive of India. ${ }^{32}$

Recent Goethe Institute projects in India include:

- Fast-track program. Until recently, after finishing the secondary school in India, students could enter a German university only after completing one-year preparatory course in Germany. The Goethe Institute and the Association of the Leading Institutes of Technology in Germany signed an agreement to allow Indians to enter German technical universities without preparatory courses. ${ }^{33}$

- Restoration project. Five restorers from the Indian National Trust for Art and Cultural Heritage have been working with German restorer Renate Kant, who regularly visits the project site, to restore "Last Supper," by the German painter Johann Zoffany. The aim is to transfer theoretical and practical knowledge of restoration to Indian conservators. ${ }^{34}$

Italy

The first Goethe Institute in Italy was established in 1954 in Turin. ${ }^{35}$ Italy now has seven Goethe Institute offices with 114 employees in Rome, Milan, Turin, Genoa, Trieste, Naples

\footnotetext{
${ }^{28}$ See Goethe Institute, "Frankfurter Sommerstipendien für die besten Deutschschüler aus Frankfurts Partnerstädten,” at http://www.goethe.de/ins/de/pro/fra_partnerstaedte.pdf.

${ }^{29}$ See "Make It in Germany" at http://www.make-it-in-germany.com.

${ }^{30}$ See Goethe Institute, "Learning German in Berlin," at http://www.goethe.de/ins/de/ort/ber/ en12253209.htm and "Learning German in Munich," at http://www.goethe.de/ins/de/ort/mue/en8496821. htm.

${ }^{31}$ See Goethe Institute India, "About Us” at http://www.goethe.de/ins/in/en/lp/uun.html.

${ }^{32}$ See Goethe Institute Pune, "Über uns," at http://www.goethe.de/ins/in/de/poo/uun.html.

${ }^{33}$ See Goethe Institute India, "What Is the 'Fast Track' Programme (Studienbrücke) All About?," at http://mucz-lbv-002.goethe.de/ins/in/lp/kul/ser/sid/stb/en12423697.htm.

${ }^{34}$ See Goethe Institute India, "Über das Projekt," at http://www.goethe.de/ins/in/de/lp/kul/sup/kle/ res/6106386.html.

${ }^{35}$ See Goethe Institute Turin, “Über uns,” at http://www.goethe.de/ins/it/tur/uun/deindex.htm.
} 
and Palermo, six Goethe Centres, 20 cultural societies and 35 partner examination centres. It assists five schools in five cities. The budget in Italy is estimated at $€ 13.3$ million.

Recently projects in Italy include:

- "I'm an Italo-Berliner" collects stories about the life of Italians in Berlin and insider information on the society of the Italo-Berliner. ${ }^{36}$

- "Starting a Career in German." In May 2014 in Bari, a German-Italian seminar was devoted to the demand for employees with a knowledge of German with the goal of building a network of schools and employers and improving communication. ${ }^{37}$

- "German Week in Naples." From 22 to 26 September 2014 in Naples, a festival of German language and culture was held in Naples, with a traditional welcome day and presentation of German-language courses as well as book presentations and outdoor film screening.

\section{Japan}

The first Goethe Institute in Japan was established in 1962 in Tokyo. ${ }^{38}$ Japan now has three Goethe Institute offices with 54 employees in Tokyo, Kyoto and Osaka, one cultural society and seven partner examination centres. It assists four schools in two cities. The budget for Japan is estimated at $€ 6.3$ million.

Goethe Institutes in Japan have many corporate sponsors. For example, "150 Years of Friendship between Germany and Japan” was sponsored by Merck, Bayer, Lufthansa, Daimler, LanXess, BASF, Volkswagen, Evonik Industries, Siemens, Allianz, Shangri-La Hotel Tokyo, Boehringer Ingelheim, Kirin, STIHL, Kaercher, Beck's, Fissler, KPMG, BMW, TÜVRheinland, Wilkhahn and Commerzbank. ${ }^{39}$

The Goethe Institute Kyoto has expanded the traditional functions of a representative office to create a residence for artists. This residence maintains cultural exchange with partners in Asia. ${ }^{40}$ Its library and café were sponsored by Thonet, ERCO, Loewe, Vorwerk Carpet, WMF and Rosenthal. Its workroom and accommodation at Villa Kamogawa for artists were sponsored by the Japanese companies Kashiwa and PlusMinusZero. ${ }^{41}$

Recent projects in Japan include:

- In March and April 2014, the Goethe Institute Kyoto held an exhibition of German photographer and Villa Kamogawa scholar Anne Kathrin Greiner during the Photo-Festival Kyotographie. ${ }^{42}$

- The Goethe Institute was one of the sponsors of the 22nd Children's Film Festival in August 2014, which screened films from different countries. Germany was represented by the animated film "Pinocchio," directed by Anna Justice in 2013. ${ }^{43}$

\footnotetext{
${ }^{36}$ See Goethe Institute Italy, "Ich bin ein Italo-Berliner,” at http://www.goethe.de/ins/it/lp/kul/mag/ soz/it/deindex.htm.

${ }^{37}$ See Goethe Institute Italy, "Mit Deutsch in den Beruf," at http://www.goethe.de/ins/it/lp/lhr/mit/ deindex.htm.

${ }^{38}$ See Goethe Institute Tokyo, "50 Jahre Goethe-Institut Tokyo," at http://www.goethe.de/ins/jp/tok/ uun/g50/deindex.htm.

${ }^{39}$ See Goethe Institute Tokyo, "Förderer," at http://www.goethe.de/ins/jp/tok/uun/spo/deindex.htm.

${ }^{40}$ See Goethe Institute Kyoto, "Über uns," at http://www.goethe.de/ins/jp/kam/uun/deindex.htm.

${ }^{41}$ See Goethe Institute Kyoto, "Förderer," at http://www.goethe.de/ins/jp/kam/spo/deindex.htm.

${ }^{42}$ See Goethe Institute Kyoto, "Anne Kathrin Greiner Fotografie \& Film,” at http://www.goethe.de/ ins/jp/kam/ver/acv/bku/2014/de12436398v.htm.

${ }^{43}$ See Goethe Institute Tokyo, "22nd Tokyo Kinder Film Festival,” at http://www.goethe.de/ins/jp/tok/ ver/de13113868v.htm.
} 


\section{Kazakhstan}

The Goethe Institute has only one office in Kazakhstan - in Almaty - with 29 employees. There are also five German-language learning centres, five partner examination centres and one library. There are no Goethe Centres in the country. Eight schools are assisted in five cities. The Goethe Institute in Kazakhstan is supported by such companies as DaimlerChrysler (through its representative office for Central Asia), Lufthansa, Shell, Skoda Auto and the Hyatt Regency Almaty. ${ }^{44}$ The budget of the Goethe Institutes in Kazakhstan is estimated at $€ 3.4$ million.

Goethe Institute Kazakhstan produces relatively few cultural initiatives, although its goals and aims are the same as the rest of the organization. Many of its projects are similar to those in many other countries, such as those involving German minorities and PASCH.

The "Gletschermusik" project is an exception. Glaciers are melting as a result of global warming. To attract attention to this problem, the Goethe Institute Kazakhstan launched a project using melting glaciers as an inspiration for festivals, competitions, concerts, paintings and other cultural activities. ${ }^{45}$

\section{Mexico}

Mexico has one Goethe Institute office with 55 employees in Mexico, two German cultural centres and six partner examination centres, and supports five schools in five cities. Among the sponsors of the Goethe Institute in Mexico are Nycomed and the German Industry Cultural Foundation. ${ }^{46}$ The budget in Mexico is estimated at $€ 6.4$ million.

Recent projects put on by Mexico's Goethe Institute include:

- In August 2014, the Goethe Institute in Mexico held its 13th week of German films. This year the program included films about local challenges. The festival also showed feature and documentary films made since the 1940s. ${ }^{47}$

- In September 2014, the Goethe Institute opened a new exhibition titled "Frozen in Time: Photographs of Dance." This exhibition included a video installation of selected German choreographers and artists. ${ }^{48}$

The Goethe Institute in Mexico cooperates with other institutions to organize competitions for German media art specialists. The winners are awarded residencies for two-month stays in Mexico. ${ }^{49}$

\section{South Africa}

South Africa has one Goethe Institute office with 23 employees in Johannesburg, one Goethe Centre and seven partner examination centres. Four schools in four cities are assisted. In addition to its general aims, the Goethe Institute in Johannesburg supports South African culture and works to strengthen the intra-African dialogue though artistic debate. ${ }^{50}$ The budget for South Africa is estimated at $€ 2.7$ million.

${ }^{44}$ See Goethe Institute, “Kasachstan,” at http://www.goethe.de/ins/kz/de/alm.html.

${ }^{45}$ See Goethe Institute Kazakhstan, "Gletschermusik," at http://www.goethe.de/ins/kz/alm/kul/prk/ gle/deindex.htm.

${ }^{46}$ See Goethe Institute Mexico, "Förderer,” at http://www.goethe.de/ins/mx/de/lp/uun/spo.html.

${ }^{47}$ See Goethe Institute, "13 Deutsche Filmwoche Mexiko: 14-28 August 2014," at http://www.goethe. $\mathrm{de} / \mathrm{ins} / \mathrm{mx} / \mathrm{lp} / \mathrm{prj} / \mathrm{cin} /$ deindex.htm.

${ }^{48}$ See Goethe Institute, "Angehaltene Zeit. Bilder vom Tanz," at http://www.goethe.de/ins/mx/de/lp/ ver.cfm?fuseaction=events.detail\&event_id=20420528.

${ }^{49}$ See Goethe Institute, "Mexiko-Stipendium 2014/15 für deutsche Medienkünstler/innen,” at http:// mexiko.emare.eu.

${ }^{50}$ See Goethe Institute South Africa, "Projects,” at http://www.goethe.de/ins/za/en/joh/kul/sup.html. 
The Goethe Institute Johannesburg coordinates 11 Goethe Institutes and 14 Goethe Centres and cultural societies through sub-Saharan Africa (as a regional institute). It also works in African countries where the Goethe Institute is not represented, in cooperation with other German institutes. $^{51}$

Recent projects in South Africa include:

- "Music Around Africa." Interest in modern African music has been growing all over the world. This project introduces different musical genres popular in sub-Saharan Africa through 12 radio shows broadcast on ByteFM. Journalists and musicians from different African countries talk about music, trends in music and the cultural and political environment..$^{52}$

- GoetheOnMain" was oepened by the Goethe Institute in 2009 in Johannesburg. It is a non-profit, multidisciplinary, artist-run project space to facilitate cultural dialogue and exchange through exhibitions, seminars, film screenings, theatre and musical performances. ${ }^{53}$

\section{Ukraine}

Ukraine has one Goethe Institute office in Kiev, established in 1993, with 77 employees, three cultural societies, 15 German-language learning centres, one partner examination centre and four libraries. It assists 15 schools in 14 cities. There are no Goethe Centres. In addition to its general aims, the Goethe Institute in Kiev promotes dialogue between Europe and Eastern European cultures. The budget in Ukraine is estimated at $€ 9.0$ million.

During its first 11 years in Ukraine, the Goethe Institute office was located in the Kiev Polytechnic Institute. In 2005 it moved to a new building shared with the British Council. ${ }^{54}$ Recent projects include:

- "Promoting Models of Culture." In June and July 2014, the Goethe Institute invited a delegation from Ukraine's Ministry of Culture to Berlin and Potsdam. During its visit, the delegation studied different support models, German cultural institutions and their structures. Delegates were also briefed on funding and management models of theatre, libraries and museums. ${ }^{55}$

- Children's film festival. In May and June 2014, the first international children film festival was held in several Ukrainian cities. The Goethe Institute, which presented animation films by German film director Lotte Reiniger, was one of the festival's sponsors. ${ }^{56}$

\section{United Kingdom}

The first Goethe Institute in United Kingdom was established in 1962 in London. ${ }^{57}$ Today, the UK has two Goethe Institute offices with 69 employees in London and Glasgow, three partner examination centres and four PASCH schools assisted by the Goethe Institute. The Goethe Institute budget for the UK is estimated at €8.1 million.

\footnotetext{
${ }^{51}$ See Goethe Institute South Africa, "About Us," at http://www.goethe.de/ins/za/en/joh/uun.html.

${ }^{52}$ See Goethe Institute South Africa, "Music Around Africa,” at http://www.goethe.de/ins/za/en/joh/ $\mathrm{kul} / \mathrm{sup} / \mathrm{iad} / 10038097 . \mathrm{html}$.

${ }^{53}$ See Goethe Institute, "GoetheOnMain," at http://www.goethe.de/ins/za/en/joh/kul/sup/gom. html?wt_sc=goetheonmain.

${ }^{54}$ See Goethe Institute Ukraine, "Über uns," at http://www.goethe.de/ins/ua/kie/uun/deindex.htm.

${ }^{55}$ See Goethe Institute Ukraine, "Modelle der Kulturförderung," at http://www.goethe.de/ins/ua/de/ kie/acv.cfm?fuseaction=events.detail\&event_id=13059386.

${ }^{56}$ See Goethe Institute Ukraine, "I. Internationales Kinderfilmfestival 'Children Kino Fest," at http:// www.goethe.de/ins/ua/kie/acv/flm/2014/de12891362v.htm (accessed: 15.08.2014).

${ }^{57}$ See Goethe Institute London, "50 Years Goethe-Institut London 1962-2012” at http://www.goethe. de/ins/gb/lon/uun/50j/en9324521.htm.
} 


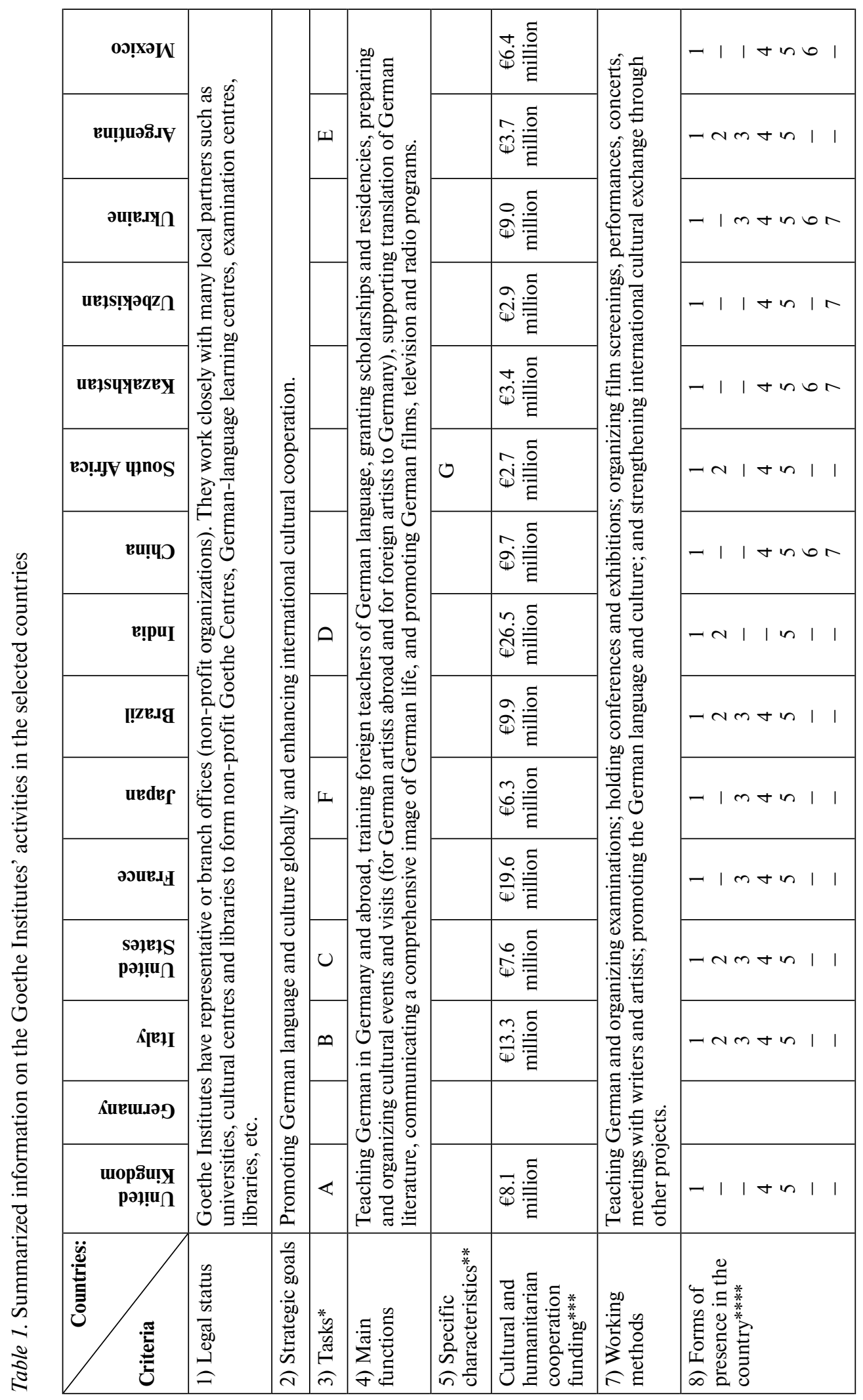


* General tasks in all countries include promoting the German language abroad, encouraging international cultural collaboration, and developing a contemporary image of Germany by providing information on cultural, civil and political life. In addition:

A United Kingdom: increasing openness in the Europe, participating in European educational initiatives such as promoting multilingualism, discussing contemporary European issues with British partners;

B Italy: supporting European dialogue on culture and education and supporting cultural dialogue between Europe and non-European cultures, especially in the Mediterranean world;

C United States: building transatlantic cultural and educational ties;

D India: focusing on film in Pune;

E Argentina: supporting an open discussion about the tension between the market and society, society and the individual, and globalization and cultural identity.

** Two Goethe Institutes have unique characteristics:

F Kyoto: provides a residence for artists, which enhances the traditional functions of a representative office by facilitating creative cultural exchange with partners in Asia.

G Johannesburg: functions as a regional institute by coordinating 11 Goethe Institutes and 14 Goethe Centres and cultural societies in sub-Saharan Africa and working in African countries in cooperation with other German institutes where the organization has no representation.

*** Funding sources: German Foreign Office provides approximately $60 \%$; tuition and examination fees provide about $35 \%$; other sources including sponsors.

**** Presence in Germany and abroad take the following forms:

1 Goethe Institutes;

2 Goethe Centres;

3 Cultural societies;

4 Partner examination centres;

5 Schools assisted by the Goethe Institute;

6 German-language learning centres (or German cultural centres);

7 Reading rooms.

In addition to promoting German-language knowledge and cultural exchange and communicating a comprehensive image of German life, the Goethe Institutes aim to increase openness in the European area through participating in European educational initiatives such as promoting multilingualism and discussing contemporary European issues with British partners. ${ }^{58}$

Recent projects include:

- "Double-gangers in Europe." Two people in the same profession meet to explore the role of their profession in the broad European context. They discuss the differences and similarities in their work, new or unique aspects of their industry in the UK, Germany and Europe.

- "AS/A2 Level Materials" allows foreign students to learn German and pass tests free of charge. ${ }^{59}$

\section{United States}

The first Goethe Institute in the United States was established in 1967 in Boston. ${ }^{60}$ The U.S. now has seven Goethe Institutes with 65 employees (according to the website, although this seems too low) in New York, Washington, Los Angeles, San Francisco, Chicago and Boston, plus one Goethe Centre, three cultural societies and 42 partner examination centres. Nine schools are assisted by the Goethe Institute in eight cities. Sponsors include Deutsche Bank,

\footnotetext{
${ }^{58}$ See Goethe Institute United Kingdom, “About Us,” at http://www.goethe.de/ins/gb/lp/uun/enindex. htm. dex.htm.

${ }^{59}$ See Goethe Institute, "AS/A2 Levels Materials," at http://www.goethe.de/ins/gb/lon/prj/asa/dein-

${ }^{60}$ See Goethe Institute Boston, “About Us,” at http://www.goethe.de/ins/us/bos/uun/enindex.htm.
} 
Lufthansa, Lufthansa Cargo, Robert Bosch Fund and Alfried Krupp von Bohlen and Halbach Fund.$^{61}$ The budget of the Goethe Institutes in the United States is estimated at $€ 7.6$ million.

In addition the usual goals such as promoting the German language and German culture, in the U.S. Goethe Institutes also work to build a transatlantic cultural and educational community. ${ }^{62}$

In 1996, the sponsors and members of the Goethe Institute in Atlanta created the Friends of Goethe, Inc., a non-profit organization Friends of Goethe, Inc. to raise funds to support the cultural programs. In 2007 the Goethe Institute in Atlanta and Friends of Goethe became one entity called the Goethe Centre Atlanta. ${ }^{63}$

Recent projects in the United States include:

- "Artists in Residence in New England" covers more than 150 universities and colleges in the Boston area and offers artist residencies for periods from two weeks to two month to take part in debates and to give lectures. ${ }^{64}$

- "Helen and Kurt Wolff Translator's Prize." The Goethe Institute Chicago awards this prize annually for the best literary translations from German into English. The prize is financed by the German government. The winning translations receive USD 10,000. ${ }^{65}$

- Goethe Institute San Francisco's "Step into German” teaches students German through music, film and soccer. Students participate in video contests with a three-week language class at the Goethe Institute in Germany as the main prize. ${ }^{66}$

\section{Uzbekistan}

The Goethe Institute began its work in Tashkent in 1998. ${ }^{67}$ Uzbekistan still has only one Goethe Institute office with 25 employees, one partner examination centre and two libraries and assists 13 schools in eight cities. There are no Goethe Centres or cultural societies in Uzbekistan. The budget for Uzbekistan is estimated at $€ 2.9$ million.

Most of the Goethe Institute's cultural projects in Uzbekistan are produced by the institute and its partners at the international level, such as the PASCH Initiative.

\section{Conclusions and Recommendations for Russia}

Goethe Institutes are successful in promoting German language and culture. The number of foreign citizens learning German and taking examinations at Goethe Institutes or their partners has been growing. Every year the institute organizes and participates in thousands of cultural events worldwide. These events promote German writers and artists abroad and introduce foreign visual arts, films, theater and music to the German public.

Although the Goethe Institute is funded mainly by the German Foreign Office, it is an independent nonprofit organization. Politics and political propaganda usually stay off its agenda.

\footnotetext{
${ }^{61}$ See Goethe Institute USA, "Sponsors," at http://www.goethe.de/ins/us/lp/spo/enindex.htm.

${ }^{62}$ See Goethe Institute USA, "Mission Statement," at http://www.goethe.de/ins/us/lp/uus/auz/enindex.htm.

${ }^{63}$ See Goethe Institute Atlanta, "About Us,” at http://www.goethe.de/ins/us/atl/uun/enindex.htm.

${ }^{64}$ See Goethe Institute Boston, "Artists in Residence in New England," at http://www.goethe.de/ins/us/ bos/ver/air/enindex.htm.

${ }^{65}$ See Goethe Institute USA, "Helen and Kurt Wolff Translator's Prize,” at http://www.goethe.de/ins/ us/lp/kul/mag/lit/rec/enindex.htm.

${ }^{66}$ See Goethe Institute, "Step into German," at http://www.goethe.de/ins/us/saf/prj/stg/enindex.htm.

${ }^{67}$ See Goethe Institute Tashkent, "10 Jahre Goethe-Institut Taschkent,” at http://www.goethe.de/ins/ uz/tas/uun/10j/deindex.htm.
} 
Moreover, Goethe Institute's programs focus on promoting peace, openness, cooperation, environmental management and other social values.

Goethe Institute activities appeal to foreign citizens of all ages, from school students (through the PASCH project) to accomplished artists (through cultural exchange programs). In fact, high teaching standards, dissemination of information about life and work in Germany, and scholarships for German-language courses allow the Goethe Institute to attract the most talented young people to study and work in Germany. These people can later contribute to Germany's science, culture and economy.

An important part of the Goethe Institute's activities is broad-scale cooperation with other organizations, such as universities, libraries, cultural centres, companies and embassies. These organizations act as partners by providing their buildings and equipment for cultural events. Some (mostly companies) sponsor events; others provide facilities for examination centres, learning centres, libraries and so on.

To sum up, the activities of the Goethe Institute improve Germany's reputation abroad, enhance the quality of German-language teaching, contribute to the development of the German language, promote German artists world-wide, and attract talented foreign youth and professionals to Germany.

Given the Goethe Institute's long experience in expanding its network of cultural centres and increasing their influence abroad, Russia should take maximum advantage of its own achievements in cultural exchanges, concentrating on cooperation with various organizations such as companies, universities, educational centres, libraries and embassies. When possible, Russia should use the experience and contacts of existing cultural centres. New contacts and partners are also urgently needed, since such partnerships save costs (through using buildings, equipment and other resources of partners) and increase audiences. This cooperation should eventually focus on a broad audience from children to experts.

Russian cultural centres need to extend their networks of national and foreign sponsors and partners who are interested in joint seminars, festivals, exhibitions, disputes and other events. Films, theatre, painting and sculpture as well as historical dates could be suitable themes for such projects. Special attention must be paid to translating Russian literature into foreign languages.

Russian cultural centres must be independent. They should have little relation to political events, because the politicization of cultural cooperation will inevitably fail to make Russia attractive to foreign tourists, young and talented people and accomplished professionals and artists. Nor will it improve Russia's image abroad. Political issues in cultural events and education are usually obvious.

Despite the current geopolitical tensions, Russia offers opportunities for international partnerships in the sphere of culture and language. Despite the degradation in the quality of its science and education since the fall of the communism, some Russian universities have preserved or created high standards in education and research, which may remain attractive to foreign colleagues. Russia also has many famous musicians, film makers and animators as well as artists who are not widely known by the broad public, but whose work may increase interest in Russia and its culture in other countries.

Special attention should be given to innovative and non-standard programs of cultural exchange and language promotion, such as those used by the Goethe Institute. Opportunities with high potential include creative exhibitions, projects to introduce unknown Russian artists and learning through online games.

Russia should also develop cultural centres within its own borders to host and train people who want to learn to speak Russian. These centres should offer a broad range of courses and 
cultural programs. They should be located in small Russian towns with a rich historical and cultural heritage and picturesque views, as well as with developed infrastructure and good accessibility. Russian cultural centres will give a positive and comprehensive picture of Russia to foreign students and improve the country's image abroad.

\section{References}

Goethe Institute (2004) Rahmenvertrag zwischen der Bundesrepublik Deutschland und dem Goethe-Institut e.V. Munich. Available at: https://www.goethe.de/resources/files/pdf11/Rahmenvetrag_Goethe-Institut.pdf (accessed 30 March 2015).

Goethe Institute (2009) Satzung vom 21 September 2000 i. d. F. vom 20 November 2009. Munich. Available at: https://www.goethe.de/resources/files/pdf11/Vereinssatzung_Goethe-Institut.pdf (accessed 30 March 2015).

Goethe Institute (2013) Rechenschaftsbericht 2012/2013. Munich. Available at: http://www.goethe.de/uun/ pro/jb13/Rechenschaftsbericht2012-2013.pdf (accessed 30 March 2015).

Goethe Institute (2014) Jahrbuch 2013/2014. Munich. Available at: https://www.goethe.de/resources/files/ pdf26/Jahrbuch-Goethe-Institut_20141.pdf (accessed 30 March 2015). 